\title{
Towards a Global Social Support System: A Response to the Recent Commentaries
}

\author{
Martin McKee $^{\mathbf{l}^{*}}$, Gorik Ooms ${ }^{2}$, David Stuckler ${ }^{1,3}$, Sanjay Basu ${ }^{4}$
}

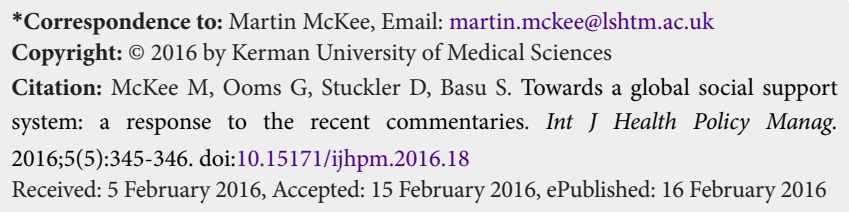

$\mathrm{W}$ hen we invoked the example of the US National Basketball Association's (NBA's) scheme for redistribution of new talent as a model offering lessons for a possible future global social support system we hoped that we would stimulate debate. Consequently, we are very grateful to Goldblatt ${ }^{1}$ and Labonté ${ }^{2}$ for their insightful commentaries that explore some of the issues that arise from our suggestion.

As Goldblatt notes, we did not propose that the NBA scheme be used as a blueprint for a global system, but rather as an illustration of a principle that could be applied more widely. We agree fully about the importance of incorporating proportionate universalism, establishing appropriate and effective governance structures, and taking action that is of adequate scale and intensity. Goldblatt correctly makes the point that a global system should not simply rob from the rich to give to the poor but instead should draw resources from countries all levels of development, including the very poorest, on the basis of ability to pay and should redistribute those resources, again to all countries, on the basis of need. We have described in detail how this might work elsewhere. ${ }^{3}$ The concept of solidarity that underpins this idea is entirely different from that of charity. Crucially, it is designed to avoid a "them and us" mentality but rather to encourage those who contribute most to realise that it is in their best long term interests to do so. ${ }^{4}$

This approach explicitly recognises that situations can change, whether for individuals or entire countries. Countries that were once wealthy can become poor. The downward economic trajectory of Argentina during the 20th century offers an example. ${ }^{5}$ Conversely, those that were once poor can become extremely rich, as has been the case with many countries that have been fortunate to find large oil reserves, but as recent events have shown, the economic benefits can be extremely transient. Goldblatt also notes, correctly, that the scale of transfers would be immense. However, this should be set against the enormous transfers that have taken place in the past few decades, leading to a situation where a small number of individuals have managed to control much of the world's total wealth. Even if we could reverse the scale of the transfer that has taken place since 1980, we would have made enormous progress. Finally, Goldblatt emphasises the need to tackle the legacy problems confronting countries. Put simply, those that have been unable to invest in the creation of strong educational systems and to build physical infrastructure will lack the capacity to absorb additional resources on a large scale. Consequently, any redistribution must be accompanied by extensive technical assistance, while recognising that change will take time, in many cases a decade or more.

Labonté also supports the principle set out in our paper but raises questions as to how the idea might work in practice on a global scale. His points are important and we welcome the opportunity to address them here. First, he draws attention to how global corporations have been able to employ tactics such as transfer pricing to ensure that their profits are launched in low tax jurisdictions. This leads to some patently ridiculous situations. For example, it is arguable that a well-known coffee chain is only operating in the United Kingdom out of a sense of altruism, as apparently it consistently made a loss throughout the first decade of the 21 st century. ${ }^{6}$ Of course, there is more to this than meets the eye. It does so by paying royalties for the use of its brand, along with a number of other financial processes, to ensure that any tax liability falls in the low tax Netherlands or Switzerland. While perfectly legal, now these arrangements have become a matter of public knowledge, they are increasingly viewed as unacceptable. Fortunately, the European Union (EU) has resolved to act, plugging a gap that national governments had too long ignored. Labontés second point is related, highlighting the importance of measures to prevent the same corporations from sheltering their money in offshore tax havens. Again, this is something that several national governments, and particularly those such as the United Kingdom and the Netherlands that have overseas dependencies, have singularly failed to act upon. ${ }^{7}$

Labontés third point goes much further beyond what we sought to tackle in our paper. Echoing more recent work by Piketty, ${ }^{8}$ he reminds us that, in recent decades, the return on capital has been much greater than that on labour. Others might go further and argue that the imbalance is not so great that it threatens the global capitalist system, with the stagnation affecting many countries reflecting a lack of aggregate demand by low paid workers, no longer benefiting from the protection provided by strong trade unions. Again, this is an area where we are in full agreement. However, as noted above, it goes far beyond the scope of our paper. The same is true for Labontés final point, where he reminds us of the continuing debate about the limits to growth. ${ }^{9}$

To conclude, we are delighted that both commentators have endorsed the idea that we have put forward but we agree with

Full list of authors' affiliations is available at the end of the article. 
both that more work is required to turn this idea into a reality.

Ethical issues

Not applicable.

\section{Competing interests}

Authors declare that they have no competing interests.

Authors' contributions

MM drafted the response, which all authors then commented on.

\section{Authors' affiliations}

${ }^{1}$ European Centre on Health of Societies in Transition, London School of Hygiene and Tropical Medicine, London, UK. ${ }^{2}$ Protection International, Brussels, Belgium. ${ }^{3}$ Department of Sociology, Oxford University, Oxford, UK. ${ }^{4}$ School of Medicine, Stanford University, Stanford, CA, USA.

\section{References}

1. Goldblatt P. How can a global social support system hope to achieve fairer competiveness? Comment on "A global social support system: what the international community could learn from the United States' National Basketball Association." Int J Health Policy Manag. 2016;5(3):205-206. doi:10.15171/ ijhpm.2015.211

2. Labonté R. From the myth of level playing fields to the reality of a finite planet; Comment on "A global social support system: what the international community could learn from the United States' National Basketball Association." Int J Health Policy Manag. 2016;5(2):137-139. doi:10.15171/ijhpm.2015.202

3. Basu S, Stuckler D, McKee M. An alternative mechanism for international health aid: evaluating a Global Social Protection Fund. Health Policy Plan. 2014;29(1):127-136. doi:10.1093/ heapol/czs141

4. McKee M, Stuckler D. The assault on universalism: how to destroy the welfare state. BMJ. 2011;343:d7973. doi:10.1136/ bmj.d7973

5. Della Paolera G, Taylor AM. A New Economic History of Argentina. Cambridge: Cambridge University Press; 2003.

6. MacAlister T. Starbucks pays corporation tax in UK for first time in five years. The Guardian. 2013. http://www.theguardian.com/ business/2013/jun/23/starbucks-pays-corporation-tax:2013.

7. Palan R, Murphy R, Chavagneux C. Tax Havens: How Globalization Really Works. Ithaca, NY: Cornell University Press; 2013.

8. Piketty T. Capital in the Twenty-First Century. Cambridge, MA: Harvard University Press; 2014.

9. Meadows D, Randers J, Meadows D. Limits to Growth: The 30-Year Update. White River Junction, VT: Chelsea Green Publishing; 2004. 